\title{
Regulation of CTP : phosphocholine cytidylyltransferase in HepG2 cells: effect of choline depletion on phosphorylation, translocation and phosphatidylcholine levels
}

\author{
Paul A. Weinhold *, Linda Charles and Douglas A. Feldman \\ Medical Research, VA Medical Center and Department of Biological Chemistry, University of Michigan Medical School, \\ 2215 Fuller Road, Ann Arbor, MI 48105 (USA) \\ (Received 11 May 13) \\ (Revised manuscript received 8 September 1993)
}

Key words: HepG2 cell; Choline deficiency; Cytidylyltransferase; Phosphatidylcholine synthesis; Methylation pathway; Phosphorylation

\begin{abstract}
We studied the effect of choline depletion on the biosynthesis of phosphatidylcholine (PC) and the distribution and phosphorylation of cytidylyltransferase (CT) in HepG2 cells. Phosphocholine concentrations decreased within $24 \mathrm{~h}$ of choline depletion to values less than $2 \%$ of controls. The incorporation of $\left[{ }^{3} \mathrm{H}\right]$ glycerol into $\mathrm{PC}$ was reduced in choline-depleted (CD) cells. The apparent turnover of PC was similar in $\mathrm{CD}$ and choline-supplemented (CS) cells $\left(T_{1 / 2}=20 \mathrm{~h}\right)$. The methylation pathway for PC synthesis increased nearly 10-fold in CD cells. Cell growth was similar in CD and CS cells. Over 95\% of CT activity in CS cells was in the soluble pool. Choline depletion resulted in a progressive decrease in CT activity and immunodetected enzyme in the soluble pool and a corresponding increase in membrane CT over a 48-h period. Choline supplementation of CD cells caused a rapid release of membrane CT (complete release by $3 \mathrm{~h}$ ). Two phosphorylated forms of CT were identified. One form contained a higher level of phosphorylation (HPCl) then the other form (LPCT). HPCT migrated slightly slower than LPCT on SDS gels. CD cells contained only LPCT in both soluble and membrane pools. CS cells contained only HPCT. During choline depletion PC content decreased nearly $20 \%$ but CT binding did not occur until LPCT was generated in cytosol. Conversely, choline supplementation released LPCT into cytosol and HPCT was formed only after the release. We conclude that both the induction of binding sites, perhaps by depletion of PC and dephosphorylation of HPCT to LPCT, are required for CT translocation to membranes. The release of CT from membranes is initiated by changes in membrane binding sites followed by trapping of the CT in the soluble pool by phosphorylation of LPCT to HPCT.
\end{abstract}

\section{Introduction}

CTP : phosphocholine cytidylyltransferase (CT) is a major regulatory enzyme in the biosynthesis of phosphatidylcholine. A large amount of information has accumulated about the catalytic and regulatory properties of this enzyme (for recent reviews see Refs. 1,2). A translocation model has emerged from these studies as a central part of the regulatory mechanism. In this model inactive, soluble CT is translocated to membranes, where it becomes active. However, the mecha-

\footnotetext{
* Corresponding author. Fax: + 1 (313) 7617693.

Abbreviations: CT, CTP: phosphocholine cytidylyltransferase; PC, phosphatidylcholine; ECL, enhanced chemiluminescence; LPSR, low protein serum replacement; PBS, phosphate-buffered saline; PMSF, phenylmethylsulfonylfluoricle; MEM, Eagle's minimal essential medium supplemented with nonessential amino acids; FBS, fetal bovine serum; SDS-PAGE, sodium dodecyl sulfate-polyacrylamide gel electrophoresis.
}

nisms involved in CT translocation remain unclear, partly because of the difficulty in reconciling results obtained from a variety of experimental models. For example, fatty acid treatment of cells increases the incorporation of radioactive phosphocholine into phosphatidylcholine with a coincident increase in membrane CT activity [3-11]. Sometimes the increase in membrane enzyme is clearly due to translocation from the soluble pool $[3,4]$. But, in other cases, the membrane activity increases without a corresponding decrease in soluble activity [5-11]. Another example arises from studies on the phosphorylation of CT. Cytidylyltransferase is phosphorylated [12-14] and evidence suggests that phosphorylation may control the binding of CT to membranes [13-16]. However, phorbol ester and cAMP treatment of cells affects the synthesis of phosphatidylcholine but does not change the overall extent of CT phosphorylation $[13,14,17]$. In other studies, the elevation of cAMP-dependent protein kinase in rat hepatocytes did not change the rate of PC synthesis 
or the phosphorylation state of CT [18]. Finally, CT activity in membranes increases after choline depletion of LM fibroblasts [19], CHO-K1 cells [20] and type I pneumonocytes isolated from adult rat lung [21]. Cytidylyltransferase activity in membranes also increases in hepatocytes isolated from choline and methionine deficient rats $[22,23]$. Choline supplementation of hepatocytes isolated from choline-methionine deficient rats increases the phosphatidylcholine levels with a corresponding decrease in membrane $\mathrm{CT}$ activity. These results led to the hypothesis that the amount of phosphatidylcholine in membranes regulates the binding of CT. However, it seems unlikely that changes in membrane phosphatidylcholine is a universal prerequisite for cytidylyltransferase binding to membranes because phospholipase $\mathrm{C}$ treatment of cells increases phosphatidylcholine synthesis and membrane-bound. CT activity but does not change the phosphatidylcholine content [24]. Furthermore, fatty acid treatment of Krebs II cells promotes membrane binding of CT without any measurable change in phosphatidylcholine levels [25]. Evidence has also been presented suggesting that translocation induced by $12-O$-tetradecanoyl phorbol-13-acetate in HeLa cells is mediated by increased diacylglycerol [17]. Furthermore, preliminary results suggested that phosphorylation of CT was not involved in the translocation of CT induced by choline depletion of rat hepatocytes [23]. One explanation for these apparent disparate results is that $\mathrm{CT}$ activity is regulated by different mechanisms depending upon the functional requirements of the cells. This would be similar to a number of regulatory enzymes that are controlled by both allosteric modulation and phosphorylation. It is also possible that a common mechanism does exist but has escaped recognition due to an incomplete understanding of the relationship between events that trigger a regulatory response and the mechanisms altering the catalytic activity of $\mathrm{CT}$.

Hepatocytes, isolated from choline-methionine deficient rats, provide a useful model to study the translocation mechanism [22,23]. However, this model has some experimental limitations. Choline depletion is produced in the intact rat. 'L'hus, detailed analysis of the changes in lipid content and CT activities are not easily followed during the choline depletion phase of the model. A cell line that remains viable under choline-deficient conditions would facilitate a more detailed description of the response and enable a more precise analysis of the molecular mechanisms involved in CT translocation.

The HepG2 cell line, derived from human hepatoblastoma [26] retains a high degree of differentiated hepatocyte function and has becn used cxtensively to study the regulation of lipid and lipoprotein metabolism [27]. We reported previously that phosphatidylcholine synthesis in HepG 2 cells is increased by fatty acids with a corresponding translocation of $\mathrm{C}$ activisy [11], The purpose of the present study was to examine the effects of choline depletion on the regulation of CT ransiocation. The results provided evidence that both the state of CT phosphorylation and content of phosphatidycho line are important in regulating the amount of menbrane-bound $\mathrm{CT}$.

\section{Experimental procedures}

Materials. We purchased Minimum Essential Medium with Eagle's salts and L-glutamine ( $\# 320-1095 \mathrm{PJ}$ ) (MEM) and choline-deficient MEM fron Gibco. Fetal bovine serum (heat inactivated) was obtained from Hyclone Laboratories. Digitonin (\#D-1407), CTP, CDP-choline, anti rabbit IgG conjugated to horseradish peroxidase, and low protein serum replacement (LPSR) were purchased from Sigma Chemical Co. Radioactive Chemicals, [methyl ${ }^{14} \mathrm{C}$ phosphocholine, [U. ${ }^{3} \mathrm{H}$ ]glycerol, CDP-[methyl- $\left.{ }^{14} \mathrm{C}\right]$ choline, $\left[\mathrm{U}-{ }^{14} \mathrm{C}\right]$ serine, $\left[\mathrm{U}^{-14} \mathrm{C}\right]$. ethanolamine, $\left[{ }^{14} \mathrm{C}\right.$-methylmethionine, $\left[{ }^{3} \mathrm{H}\right] \mathrm{CT}$ and ${ }^{32} \mathrm{PO}_{4}$ were obtained from New England Nuclear. Enhanced chemiluminescence reagent (ECL) was from Amersham. Antiserum raised against an N-terminal sequence of CT [28] was provided by Dr. Claudia Kent. Antibodies raised against CT purified from recombinant baculovirus-infected insect cells [29] was prepared by Dr. James MacDonald in Dr. Claudia Kent's laboratory. Antibodies raised against a peptide containing an internal sequence of CT [14] was provided by Dr. Dennis Vance.

Cells. HepG2 cells were obtained as described previously [11]. We cultured cells on collagen-coated tissue culture dishes in MEM containing $10 \%$ fetal bovine serum (FBS), 100 units/ml penicillin, and $100 \mu \mathrm{g} / \mathrm{ml}$ streptomycin. We subcultured cells every 5-6 days [10-cm dishes, $1: 10$ split).

We used Vitrogen 100 (a purified collagen prepara. tion obtained from Celtrix Laboratories, Palo Alto, CA) to prepare collagen coated culture dishes. Vitrogen was diluted in sterile $1 \%$ acetic acid to a-final concentration of $5 \mathrm{mg}$ collagen/100 $\mathrm{ml}$. We added 8 $\mathrm{ml}$ to a $10-\mathrm{cm}$ culture dish. The dishes were incubated at $37^{\circ} \mathrm{C}$ overnight. We removed the acetic acid solution and rinsed the dishes 2 times with PBS (Dulbecco's phosphate-buffered saline without $\mathrm{Ca}^{2+}$ and $\mathrm{Mg}^{2+}$, Gibco).

HepG2 cells were also grown in MEM containing $2 \%$ LPSR. In these experiments HepG2 cells were subcultured in MEM $+10 \%$ FBS and grown for $24 \mathrm{~h}$ The medium was then changed to MEM $+2 \%$ LPSR.

Cell fractionations. We scraped cells from culture dishes into PBS. Cells were collected by centrifugation at $800 \times g$ for $10 \mathrm{~min}$. We homogenized cells in $50 \mathrm{mM}$ Tris $/ 0.15 \mathrm{M} \mathrm{NaCl} / 2.0 \mathrm{mM}$ EDTA $(\mathrm{pH} 7.5)$ contain ing $100 \mathrm{mM} \mathrm{KF}, 1 \mu \mathrm{g} / \mathrm{ml}$ pepstatin, $1 \mathrm{~kg} / \mathrm{ml}$ lew 
peptin and $0.3 \mathrm{mM}$ PMSF. (Buffer A). The cell pellet was suspended in buffer A [500 $\mu 1$ for cells from one 10- $\mathrm{cm}$ dish). We used a precision ball-bearing homogenizer [30] to break the cells. This homogenizer was purchased from $\mathrm{H}$ and $\mathrm{Y}$ Enterprise, Redwood City, CA. We centrifuged the homogenate at $200 \times g$ for 10 min to remove unbroken cells and debris. The pellet was small and did not contain appreciable CT activity. Total particulate and cytosol were then prepared by centrifugation at $100000 \times g$ for $60 \mathrm{~min}$.

Digitonin permeabilization was performed as described previously [31]. After removal of the digitonin released supernatants, the cell ghosts were suspended in $400 \mu 1$ of buffer $A$ and sonicated $(15 s \times 2)$ to obtain a uniform suspension of broken cell ghosts. This suspension was designated the total particulate fraction.

Cytidylyltransferase assay. Cytidylyltransferase activity was determined as previously described [32]. The reaction mixture for the determination of enzyme activity in cell homogenates, particulate fractions and membrane fractions was supplemented with $6.0 \mathrm{mM}$ ADP$\mathrm{Mg}^{2+}$ [33]. Under these conditions, the reaction was linear with time for $30-60 \mathrm{~min}$ and proportional to protein up to $25 \mu \mathrm{g}$ protein/assay. This modification provided considerably more accuracy and sensitivity in the determination of CT activity in membrane fractions. All assays contained phosphatidylcholine/oleic acid (1:1 molar ratio) at a final concentration of 0.5 $\mathrm{mM}$ for each lipid.

Lipid extraction. Cells from a single plate were scraped into PBS and collected by centrifugation. The cell pellet was suspended in $0.6 \mathrm{ml}$ water. Aliquots were removed for the determination of total cellular protein. Methanol $(2.0 \mathrm{ml})$, chloroform $(1.0 \mathrm{ml})$ and 12 $\mathrm{N} \mathrm{HCl}(25 \mu \mathrm{l})$ were added to the cell suspension. After about $1 \mathrm{~h}, 1.0 \mathrm{ml}$ chloroform and $1.0 \mathrm{ml}$ water were added and the phases were separated by centrifugation. The chloroform layer was washed once with 2.0 $\mathrm{ml} 50 \%$ methanol in water. The original water-methanol phase and the 50\% methanol wash were combined and used to determine water-soluble choline metabolites. The chloroform phase was then washed an additional three times with $2 \mathrm{ml}$ of $50 \%$ methanol.

Lipid analysis. The chloroform phase was evaporated to dryness with a stream of nitrogen. The lipid residue was dissolved in $100 \mu 1$ of $4: 1$ chloroform/ methanol. Phospholipids were separated by thin layer chromatography on silica gel 60 plates with the solvent system chloroform/methanol/acetic acid/water $(100: 30: 35: 3, \mathrm{v} / \mathrm{v})$. Neutral lipids were separated with the solvent system petroleum ether $\left(\mathrm{BP} 35-60^{\circ} \mathrm{C}\right) /$ diethyl ether / acetic acid (140:40:6). Lipids were visualized by brief exposure of the plate to iodine vapor. For the chemical determination of phospholipids, bands were scraped into tubes. The amount of phospholipid phosphorus was determined after digestion with $0.3 \mathrm{ml}$ perchloric acid [34]. For determination of radioactivity, silica gel from the thin-layer plates was scraped directly into scintillation vials and radioactivity was measured in a liquid scintillation spectrometer.

Phosphocholine determination. The water-methanol phase from lipid extractions was evaporated to dryness. The residue was dissolved in $100 \mu \mathrm{l}$ of $50 \mathrm{mM}$ Imidazole- $\mathrm{HCl}(\mathrm{pH} 7.0$ ) containing $0.15 \mathrm{M} \mathrm{KCl}$ and $2.0 \mathrm{mM}$ EDTA. Aliquots were used for the determination of phosphocholine.

We determined the cellular content of phosphocholine using a method based upon the conversion of $\left[{ }^{3} \mathrm{H}\right] \mathrm{CTP}$ to $\left[{ }^{3} \mathrm{H}\right] \mathrm{CDP}$-choline by partially purified CT. We used CT that was eluted from the DEAE sepharose column step in the purification method [32]. Samples or standard phosphocholine (5-25 ng) were incubated in a $100 \mu 1$ reaction mixture containing $3 \mathrm{mM}\left[{ }^{3} \mathrm{H}\right] \mathrm{CTP}$ $\left(0.5 \mu \mathrm{Ci}\right.$ /reaction), $12 \mathrm{mM} \mathrm{Mg}{ }^{2+}, 50 \mathrm{mM}$ Imidazole$\mathrm{HCl}$ buffer $(\mathrm{pH} 7.0), 0.15 \mathrm{M} \mathrm{KCl}, 2.0 \mathrm{mM}$ EDTA, phosphatidylcholine / oleic acid $(0.75 \mathrm{mM}$ of each, sonicated together) and $20 \mu \mathrm{l}$ of CT $(1.6 \mathrm{nmol} / \mathrm{min})$. The CT was in $50 \mathrm{mM}$ Tris- $\mathrm{HCl}, 0.3 \mathrm{M} \mathrm{NaCl}, 2 \mathrm{mM}$ EDTA, $30 \mathrm{mM}$ octylglucoside $(\mathrm{pH} 7.5)$. We stopped the reaction after $60 \mathrm{~min}$ with $100 \mu \mathrm{l}$ of $0.1 \mathrm{~N} \mathrm{HCl}$ containing $50 \mu \mathrm{g}$ CDP-choline. We added the mixture to the top of a column of $\mathrm{AG} 50 \mathrm{~W} \times 2,200-400$ mesh cation exchange resin in the $\mathrm{H}^{+}$form. We prepared the columns in disposable polyethylene transfer pipets (\#13-711-7, Fisher Scientific) that had the top cut open to retain the bulb as a reservoir. Glass wool was packed loosely into the tip. Ion exchange resin was added to a height of $8 \mathrm{~cm}$. We washed the columns with $10 \mathrm{ml}$ of $0.1 \mathrm{~N} \mathrm{HCl}$ before the addition of sample. After the sample was applied, the columns were eluted with $10 \mathrm{ml}$ of $0.1 \mathrm{~N} \mathrm{HCl}$ to remove $\left[{ }^{3} \mathrm{H}\right] \mathrm{CTP}$. CDP-choline was then eluted with $8 \mathrm{ml}$ of $0.1 \mathrm{~N} \mathrm{HCl}$. A $1.0 \mathrm{ml}$ sample was added to $10 \mathrm{ml}$ of Safety-Solve scintillation fluid (Research Products International). Radioactivity was measured in a liquid scintillation spectrometer with automatic quench corrections. Phosphocholine content of the unknown sample was calculated from a standard curve obtained from phosphocholine standards included in each group of reactions.

Determination of water soluble choline metabolites. Radioactive choline metabolites in the water-methanol phase of the cell extracts were separated on silica gel 60 thin-layer plates in the solvent system, methanol/ $0.9 \% \mathrm{NaCl} / 28 \% \mathrm{NH}_{4} \mathrm{OH}(10: 10: 1, \mathrm{v} / \mathrm{v})$. We exposed the plates to Kodak XAR-5 autoradiographic film for $24 \mathrm{~h}$ to locate the radioactive metabolites. The areas on the chromatogram were scraped into scintillation vials and the amount of radioactivity was determined in a liquid scintillation spectrometer.

SDS gel electrophoresis and immunoblotting. SDSPAGE was performed using either $10 \%$ or $8 \%$ polyacrylamide gels as described previously [35]. The pro- 
teins were transblotted onto PVDF membranes (BioRad). Cytidylyltransferase was detected with $\mathrm{N}$-terminal antiserum and ECL reagent as described previously [35].

Western blots of immunoprecipitated CT from ${ }^{32} \mathrm{PO}_{4}$ experiments were probed with IgG isolated from $\mathbb{N}$ terminal antiserum and radiolabeled with ${ }^{125}$. The total IgG from $\mathrm{N}$-terminal antiserum was isolated using MAPS II kit from BioRad. The isolated IgG was dialyzed against $10 \mathrm{mM}$ sodium borate $(\mathrm{pH} 8.3)$ and concentrated to $350 \mu \mathrm{l}$ with a Centricon- 10 centrifugal concentrator (Amicon). The total IgG fraction was then iodinated with $2.0 \mathrm{mCi}$ of ${ }^{125} \mathrm{I}$ according to the method described by Haisma et al. [36]. A total of 420 $\mu \mathrm{Ci}$ of $\left[{ }^{125} \mathrm{I}\right] \mathrm{IgG}$ was obtained from the total $\mathrm{IgG}$ isolated from $40 \mu 1$ of $\mathrm{N}$-terminal antiserum. Blots were probed with $25 \mu \mathrm{Ci}$ of $\left[{ }^{125} \mathrm{I}\right] \mathrm{IgG}$ (equivalent to 2.5 $\mu 1$ of $\mathrm{N}$-terminal antiserum assuming $100 \%$ recovery). The blots were processed as described previously [35], except the final washing steps were done after the primary antibody step. The blots were developed by autoradiography for $24-48 \mathrm{~h}$ at $-60^{\circ} \mathrm{C}$.

Phosphorylation of cytidylyltransferase. Cells were subcultured into $10-\mathrm{cm}$ dishes and grown for two days in MEM $+10 \%$ FBS. The medium was then replaced with choline-deficient MEM. After 2 days in the choline-deficient medium, the cells were rinsed with choline and phosphate-free MEM and cultured for $2 \mathrm{~h}$ in choline-deficient, phosphate-free medium. The medium was replaced with $5 \mathrm{ml}$ of choline-deficient, phosphate-free MEM containing $500 \mu \mathrm{Ci}^{32} \mathrm{PO}_{4}$. After $3 \mathrm{~h}$, the cells in one dish were collected to provide labeled cells under choline-deficient conditions and choline was added to other dishes to give a final 100 $\mu \mathrm{M}$ choline. The cells from the choline-supplemented dishes were collected after $2 \mathrm{~h}$ to provided labeled cells after choline supplementation. Another dish was allowed to incubate an additional $3 \mathrm{~h}$ under cholinedeficient conditions as a control for the additional exposure to ${ }^{32} \mathrm{PO}_{4}$ medium.

The cell pellet was suspended in $400 \mu 1$ of $50 \mathrm{mM}$ Tris/0.15 M NaCl/2.0 mM EDTA ( $\mathrm{pH}$ 7.5) containing $100 \mathrm{mM} \mathrm{KF}, 2 \mathrm{mM}$ sodium vanadate, $1 \mu \mathrm{g} / \mathrm{ml}$ pepstatin, $1 \mu \mathrm{g} / \mathrm{ml}$ leupeptin, and $0.3 \mathrm{mM} \mathrm{PMSF}$. Digitonin $(200 \mu 1$ of $2.5 \mathrm{mg} / \mathrm{ml}$ in the above buffer $)$ was added. After $1.0 \mathrm{~min}$, the mixture was centrifuged at $9000 \times \mathrm{g}$ for $10 \mathrm{~min}$ to isolate the digitonin supernatant (soluble) and cell ghosts. The cell ghosts were then suspended in the above buffer containing $1.0 \%$ Triton X-100 and sonicated in a cup horn sonicator for $30 \mathrm{~s}$. After $30 \mathrm{~min}$ on ice, the mixture was centrifuged at $100000 \times \mathrm{g}$ for $60 \mathrm{~min}$. The supernatant (Triton $X-100$ extract) was recovered as the solubilized particulate fraction.

The digitonin supernatants and Triton $X-100 \mathrm{cX}-$ tracts were immunoprecipitated using $\mathrm{N}$-terminal anti- serum coupled to protein A agarose. Protein A agarose (Affinica, Schleicher and Schuell) was incubated with N-terminal antiserum ( $40 \mu \mathrm{l}$ antiserum in $2 \mathrm{ml}$ of $50 \%$ (v/v) suspension of protein $A$ agarose) and the CI antibodies were coupled to the protein $A$ with a crosslinking reagent (dimethyl suberimidate) as described by the manufacturer. The coupled antibody-protein $A$ agarose was washed twice in $50 \mathrm{mM}$ Trs (pH 8.0) containing $0.1 \%$ SDS, $1.0 \%$ Tritor $X-100,0.5 \%$ deoxy cholate, $0.075 \mathrm{M} \mathrm{NaCl}, 0.5 \mathrm{mM}$ EDTA and $1 \%$ bovine hemoglobin (Buffer $B$ ) followed by 4 washes in Buffer A diluted $1: 10$ containing $0.14 \mathrm{M} \mathrm{NaCl}$ (Buffer $\mathrm{C}$ ). Coupled protein A agarose $(50 \mu 1$ of a $50 \%(\mathrm{v} / \mathrm{v})$ suspension in Buffer C) was added to siliconized mi crofuge tubes that were previously precoated with Buffer B. Samples of digitonin supematants $(250 \mu 1)$ and Triton X-100 extracts $(250, \mu 1)$ were added. The mixture was incubated at $4^{\circ} \mathrm{C}$ for 3 h on a rotary wheel mixer. The protein $A$ agarose was pelleted by centrifugation. The pellet was washed 3 times with $1.0 \mathrm{ml}$ of Buffer $\mathrm{B}$ adjusted to $2 \%$ hemoglobin, once with $1.0 \mathrm{ml}$ of $0.01 \mathrm{M}$ Tris $(\mathrm{pH} 8.0$ ) containing $0.14 \mathrm{M} \mathrm{NaCl}$, and once in $1.0 \mathrm{ml}$ of $50 \mathrm{mM}$ Tris (pH 6.8). The pellet was suspended in $110 \mathrm{mM}$ Tris $(\mathrm{pH} 6.8)$ contaning $1 \%$ SDS and $10 \%$ glycerol, and extracted 5 min in a boiling water bath. After centrifugation, the supernatant was transferred to a new siliconized tube, $\beta$-mercaptoethanol $(7 \mu 1)$ was added and the samples were bolled an additional 5 min. Proteins in the extract were separated by SDS-PAGE and transblotted onto PVDF membranes. Radiolabeled proteins were detected on the PVDF membranes by autoradiography followed by immunodetection with ${ }^{25}$ I-labeled N-terminal $\mathrm{MG}$.

Protein and DNA determination. Protein was cetermined by the Markwell modification of the Lowry assay [37], using bovine serum albumin as the standard. DNA was determined as described by Labarca and Paigen [38].

\section{Results}

\section{Choline depletion of HepG2 cells}

HepG2 cells were cultured for 4 days in MEM containing $10 \%$ FBS. The medium was then replaced with choline-deficient MEM (without FBS) or cholinedeficient MEM (without FBS) supplemented with 100 $\mu \mathrm{M}$ choline. After $24 \mathrm{~h}$ in the choline-deficient on choline-supplemented media,we collected the cells and determined the concentrations of phosphocholine. The phosphocholine concentration was $752 \pm 81 \mathrm{mmol} / \mathrm{mg}$ cell protein (means \pm S.D., $n=9$ ) in the cholinesupplemented cells compared to $8.5 \pm 3 \mathrm{nmol} / \mathrm{mg}$ cell protein (means \pm S.D., $n=9$ ) in the choline-deficient cclls. These results indicated that $24 \mathrm{~h}$ in choline-free culture media reduced the cellular choline content. 
This resulted in an inability to maintain phosphocholine levels in the cell.

To obtain a more detailed description of the depletion of choline metabolites during cell growth on choline-deficient MEM, we prelabeled cells for $24 \mathrm{~h}$ with $\left[{ }^{14} \mathrm{CH}_{3}\right]$ choline in the presence of $10 \%$ FBS. After the $24 \mathrm{~h}$ prelabeling, the medium was removed and the cells were rinsed in choline-deficient MEM. Cholinedeficient MEM was added and the cells were harvested after varying times in culture. The results are shown in Fig. 1. The intracellular levels of phosphocholine decreased by about $70 \%$ after $10 \mathrm{~h}$. At $24 \mathrm{~h}$ the intracellular levels were reduced to less than $5 \%$ of the original amounts. Radioactive CDP-choline was barely detectable (about $10 \%$ of the choline radioactivity). There was a small amount of glycero-3-phosphocholine produced. These results support the results from direct analysis of phosphocholine. Both results indicate that the phosphocholine pool was nearly depleted after $24 \mathrm{~h}$ in choline-deficient medium.

Depletion of choline did not alter the rate of growth of HepG2 cells. For example, cells were grown in complete MEM $+10 \%$ FBS for 3 days. These cells were semiconfluent after 3 days and had $2.33 \pm 0.11$ $(n=3) \mathrm{mg}$ of cell protein per $10-\mathrm{cm}$ dish. The medium was then changed to either choline-deficient or choline-supplemented MEM without FBS. After 2 more days in culture, the total cellular protein was $3.08 \pm 0.12$ $\mathrm{mg} /$ dish and $3.09 \pm 0.07 \mathrm{mg} /$ dish for choline-depleted and choline-supplemented cells, respectively. The ratio of total cellular protein to DNA was $24.7 \pm 1.5$ and $24.0 \pm 0.8$ for choline-depleted and cholinesupplemented cells. The similar protein content per DNA verified that total cellular protein was an acceptable parameter to compare cell growth and to use as a basis for comparing metabolic properties of the cells. Growth was also monitored in MEM containing $2 \%$ LPSR in place of FBS. The replacement of FBS with LPSR eliminated the possibility that the cells were obtaining choline or phosphatidylcholine from the FBS in amounts sufficient for continued growth after removal of FBS. Cells were subcultured in MEM $+10 \%$ FBS and grown for 1 day. Cells were then cultured for 3 days in choline-deficient or choline-supplemented MEM $+2 \%$ LPSR. Although growth in the presence of LPSR was slower, cells grown in cholinesupplemented or choline-deficient MEM had the same growth rate $(1.74 \pm 0.03 \mathrm{mg}$ cell protein/dish for choline-depleted vs. $1.72 \pm 0.07 \mathrm{mg}$ cell protein $/$ dish for choline-supplemented).

\section{Phosphatidylcholine synthesis}

We determined the incorporation of $\left[2-{ }^{3} \mathrm{H}\right] \mathrm{glyccrol}$ into lipids of choline-depleted and choline-supplemented cells. The results demonstrated that the rate of synthesis of phosphatidylcholine by the CDP-choline

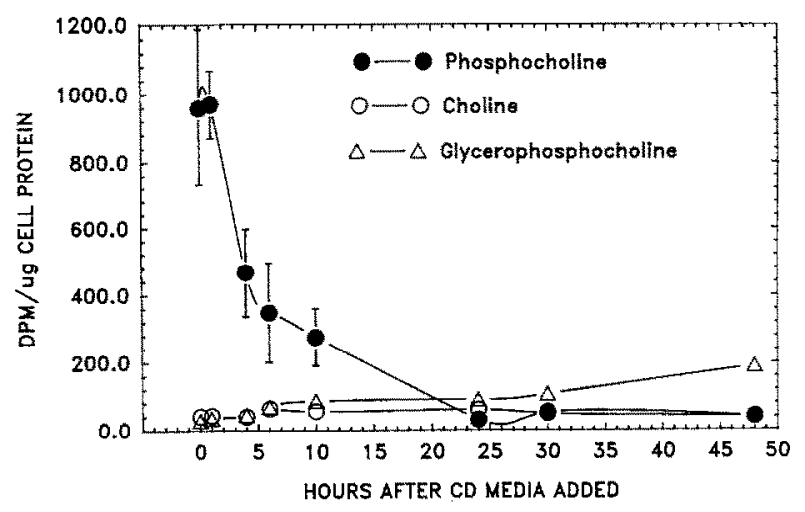

Fig. 1. The rate of decrease of choline metabolites during choline depletion. Cells were cultured for $24 \mathrm{~h}$ in MEM containing radioactive choline. The medium was then replaced with choline-deficient medium. Three dishes of cells were extracted with chloroform-methanol at the times shown. Lipids and water soluble metabolites were analyzed as described in methods. The values are means \pm S.D. for three dishes. When no S.D. bars are present, the S.D. was less than the size of the data point.

pathway was reduced in choline-depleted cells (Fig. 2). The incorporation of radioactivity from $\left[2-{ }^{3} \mathrm{H}\right] \mathrm{glycerol}$ was lower in choline-depleted cells. This was not due to the changes in diacylglycerol synthesis, since the incorporation into diacylglycerol was similar in choline-depleted and choline-supplemented cells. There was also a slight increase in incorporation of radioactivity into phosphatidylethanolamine and triacylglycerol in choline-depleted cells coincident with the decreased incorporation into phosphatidylcholine. This may reflect a shift in the competition for diacylglycerol.

The synthesis of phosphatidylcholine by the methylation of phosphatidylethanolamine was compared between choline-depleted and choline-supplemented cells. 'The methylation pathway, assessed by the incorporation into phosphatidylcholine of either $\left[{ }^{14} \mathrm{CH}_{3}\right]-$ methionine, $\left[\mathrm{U}-{ }^{14} \mathrm{C}\right] \mathrm{serine}$ or $\left[\mathrm{U}-{ }^{14} \mathrm{C}\right]$ ethanolamine, increased significantly in cells depleted of choline for 48 $\mathrm{h}$ compared to cells grown for $48 \mathrm{~h}$ in cholinesupplemented medium (Table I). Supplementation of choline-depleted cells with choline for $3 \mathrm{~h}$ decreased the methylation pathway to levels similar to those in cells supplemented with choline for $48 \mathrm{~h}$. Thus, the effect of choline on the methylation pathway appeared to be relatively rapid. Choline supplementation also produced a decrease in the incorporation of radiolabeled ethanolamine into phosphatidylethanolamine. This is probably due to competition between choline and ethanolamine for phosphorylation by choline/ ethanolamine kinase. Both choline and ethanolamine arc apparently phosphorylated by the same enzyme [2]. The results in Table I were obtained with trace amounts of ethanolamine in the culture medium. Thus the addition of $100 \mu \mathrm{M}$ choline would strongly favor the forma- 

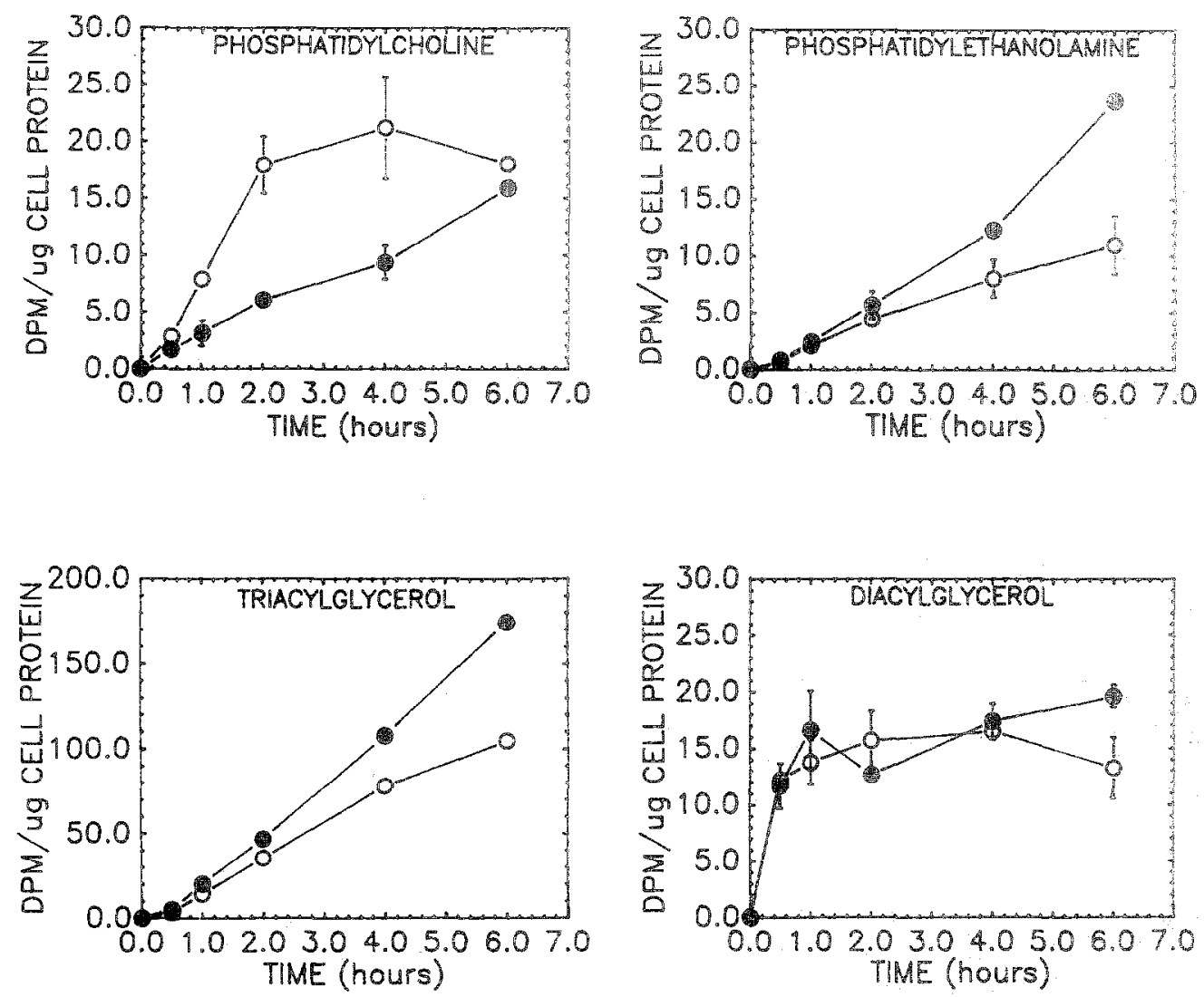

Fig. 2. Incorporation of $\left[{ }^{3} \mathrm{H}\right] \mathrm{glycerol}$ into lipids in choline-depleted and choline-supplemented cells. MepG2 cells were grown in $\mathrm{MEM}+10 \%$ FBS for 3 days in $60-\mathrm{mm}$ dishes. The medium was changed to either choline-deficient MEM or choline-deficient MEM supplenented with 100 $\mu \mathrm{M}$ choline (4 ml/dish). After $24 \mathrm{~h},\left[2-{ }^{3} \mathrm{II}\right] \mathrm{glyce}$ rol $(200 \mathrm{mCi} / \mathrm{mmol})$ was added at $5 \mu \mathrm{Ci} / \mathrm{mi}$. At the designated times, inedium was rernoved, The cells were rinsed once with ice cold PBS, extracted with chloroform-methanol, and the lipids separated by thin layer chromatography. The values are averages of three dishes \pm S.D. When no S.D. bars are present, the S.D. was less than the size of the data point. cholinemdeficient; o, choline-supplemented.

tion of phosphocholine and decrease the formation of phosphoethanolamine.

Choline and ethanolamine are relatively specific precursors for phospholipids. Serine, on the other hand, can enter the glycolytic pathway and therefore could be used for the synthesis of fatty acids and glycerol-3 phosphate. In the experiments in Table I, radioactive serine was incorporated almost exclusively into the base portion of the phospholipids. The percentage of the total radioactivity in the lipid extract that was converted to water soluble products by hydrolysis with phospholipase C was $96 \%$ for $\mathrm{CS}$ and $87 \%$ for CD.

\section{Phosphatidylcholine degradation}

To assess the degradation of phosphatidylcholine, we prelabeled cells with $\left[2{ }^{-3} \mathrm{H}\right] \mathrm{glycerol}$ for $32 \mathrm{~h}$ in MEM $+10 \%$ FBS. The medium was then replaced with either choline-deficient MEM or cholnesupplemented MEM without FBS. The amount of ta dioactivity in phosphatidylcholine was determined at

\section{TABLE I}

Comparison of the methylation pathway for phosphatidylcholine synthesis in choline-depleted and choline-supplemented cells

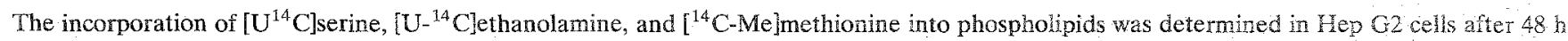
of choline depletion (CD), after $48 \mathrm{~h}$ of choline supplementation (CS), and $3 \mathrm{~h}$ of choline supplementation after $48 \mathrm{~h}$ of choline depletion. Celis

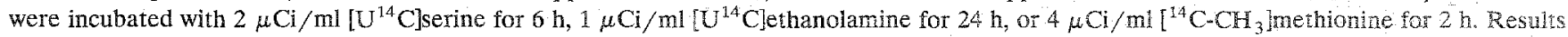
are expressed as average $\mathrm{dpm} / \mu \mathrm{g}$ cell protein \pm S.D. for three incubations.

\begin{tabular}{|c|c|c|c|c|c|c|}
\hline & \multicolumn{3}{|l|}{ Serine } & \multicolumn{2}{|c|}{ Ethanolamine } & \multirow{2}{*}{$\frac{\text { Methionine }}{\mathrm{PC}}$} \\
\hline & $\overline{\mathrm{PC}}$ & $\mathrm{PE}$ & PS & $\mathrm{PC}$ & $\mathrm{PE}$ & \\
\hline$\overline{C D}$ & $27.4 \pm 4.5$ & $26.9 \pm 5.0$ & $15.4 \pm 5.7$ & $348.5 \pm 37$ & $244.7 \pm 18$ & $84.2 \pm 2.5$ \\
\hline $\mathrm{CS}, 48 \mathrm{~h}$ & $6.4 \pm 1.8$ & $21.1 \pm 3.4$ & $15.7 \pm 5.9$ & $31.1 \pm 1.4$ & $143.9 \pm 3.6$ & $8.7 \pm 1.5$ \\
\hline $\mathrm{CS}, 3 \mathrm{~h}$ & $7.3 \pm 0.3$ & $23.1 \pm 3.4$ & $20.4 \pm 3.6$ & & & \\
\hline
\end{tabular}


varying times after the addition of the nonradioactive medium. The apparent rate of degradation of phosphatidylcholine was similar in choline-supplemented and choline-depleted cells (Fig. 3). The disappearance of radioactivity from phosphatidylethanolamine and diacylglycerol was also similar in choline-depleted and choline-supplemented cells. The time required to remove one half of the radioactivity was calculated to be $20 \mathrm{~h}, 19 \mathrm{~h}$, and $18 \mathrm{~h}$ for phosphatidylcholine, phosphatidylethanolamine, and diacylglycerol respectively.

\section{Cytidylyltransferase activity}

The rate of change in the distribution of CT activity with choline depletion and choline supplementation is shown in Fig. 4. Membrane CT activity increased progressively in cells depleted of choline (Fig. 4A). The first indication of an increase in membrane activity was observed at $10-18 \mathrm{~h}$ after cells were exposed to choline-deficient medium.

Translocation from cytosol to membranes in response to choline depletion occurs continuously for 24 $\mathrm{h}$ after the cells became choline-depleted during the first 24-h period. On the other hand, choline supplementation of choline-depleted cells resulted in a rapid release of membrane CT into the soluble pool (Fig. 4B). The results in Fig. 4B were obtained with $100 \mu \mathrm{M}$ choline supplementation. Similar results were achieved with $10 \mu \mathrm{M}$ choline (data not shown).

\section{Regulation of CT translocation}

Both phosphorylation of CT [13-16] and the phosphatidylcholine content of cellular membranes [22,23] have been implicated in the regulation of CT translocation. We examined the relationship between these two events and translocation of CT in HepG2 cells during choline depletion and choline supplementation.

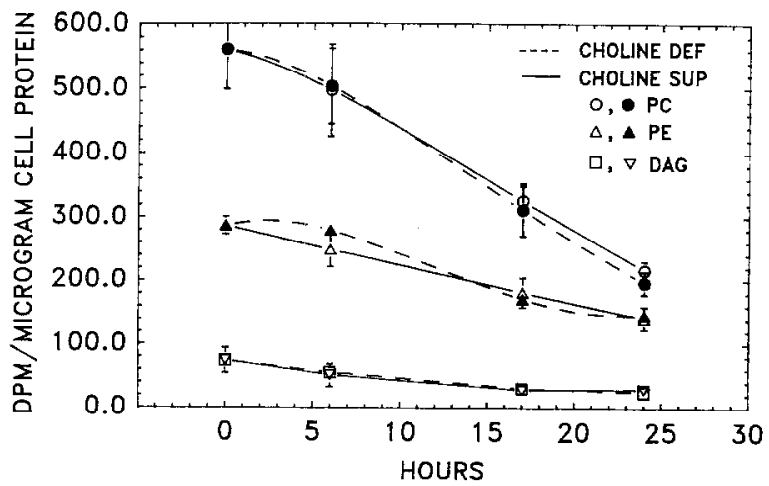

Fig. 3. Comparison of phosphatidylcholine turnover in cholinedepleted and choline-supplemented cells. Cells were prelabeled with $\left[2-{ }^{3} \mathrm{H}\right]$ glycerol for $32 \mathrm{~h}$ in MEM $+10 \%$ FBS. The medium was then changed to either choline-deficient MEM or choline-supplemented MEM $(100 \mu \mathrm{M})$ without radioactive glycerol. At the designated times, cells were collected, extracted with chloroform-methanol and lipids separated by thin layer chromatography.
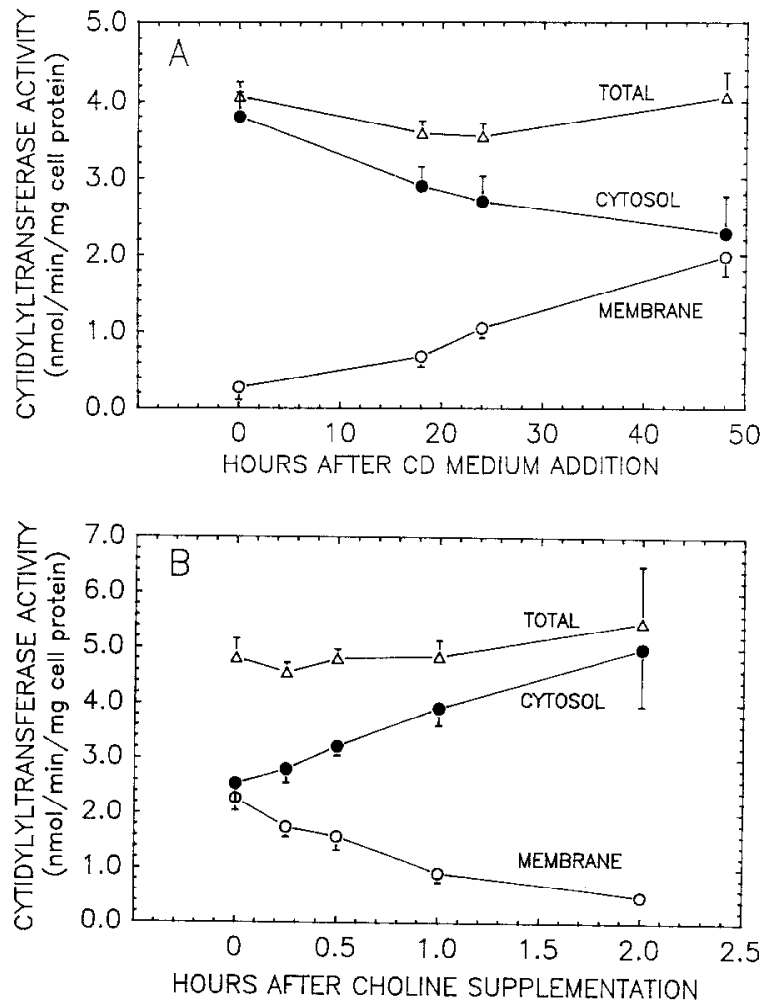

Fig. 4. Distribution of CT activity during the development of choline-depleted cells and after choline supplementation. (A) Choline depletion: cells were grown for 3 days in MEM $+10 \%$ FBS. The medium was than changed to choline-deficient MEM without FBS. Cells were collected from 3 dishes before the medium was changed (0-hour points). Cells from 3 dishes were subsequently collected at 18,24 , and $48 \mathrm{~h}$. Each dish was analyzed separately. The collected cell pellet was treated with digitonin to separate soluble CT from membrane CT. (B) Choline supplementation: cells were grown for 3 days in MEM $+10 \%$ FBS. The medium was then changed to choline-deficient MEM without FBS and cultured an additional $48 \mathrm{~h}$. The 0 -h point represents choline-depleted cells. Choline was added to the remaining dishes to give a final $100 \mu \mathrm{M}$ choline. Cells were collected at the designated times and analyzed as in (A).

Results from Kent's laboratory provided evidence for two phosphorylated forms of CT in CHO cells $[13,16]$. One form was more highly phosphorylated and migrated slightly slower on SDS gels. The two forms were detected by the $\mathrm{N}$-terminal antiserum. The $\mathrm{N}$ terminal antiserum also detected two forms of $\mathrm{CT}$ in HepG2 cells (Fig. 5A). The N-terminal antiserum was shown by Watkins and Kent to specifically detect CT on Western blots [26]. The results in Fig. 5 verify that both bands detected by the $\mathrm{N}$-terminal antiserum in HepG2 cells were forms of CT. The addition of purified $C T$ to the serum during incubations of Western blots nearly abolished the binding of antibodies to both bands (lanes 1-4 vs. lanes 5-8). Furthermore, both bands were detected by antiserum raised against CT isolated from recombinant baculovirus infected insect cells (Fig. 5B, lanes 1-3); and by affinity purified 

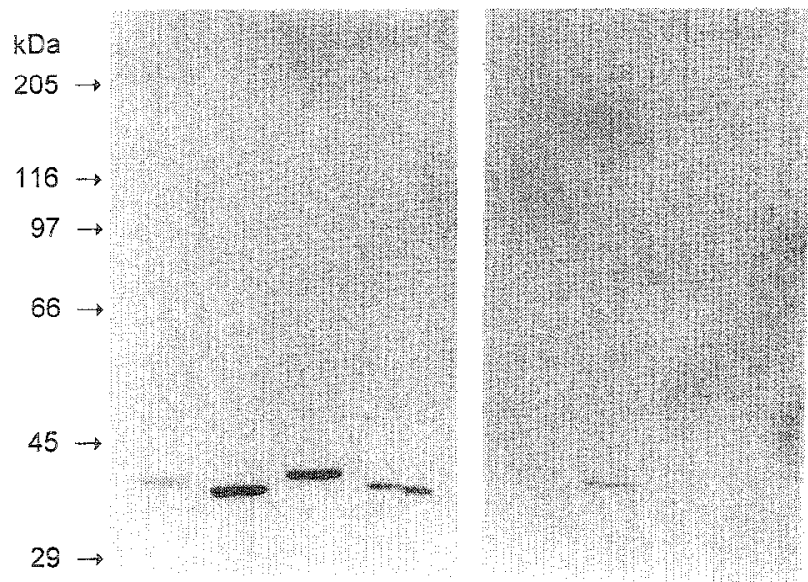

A 1

34

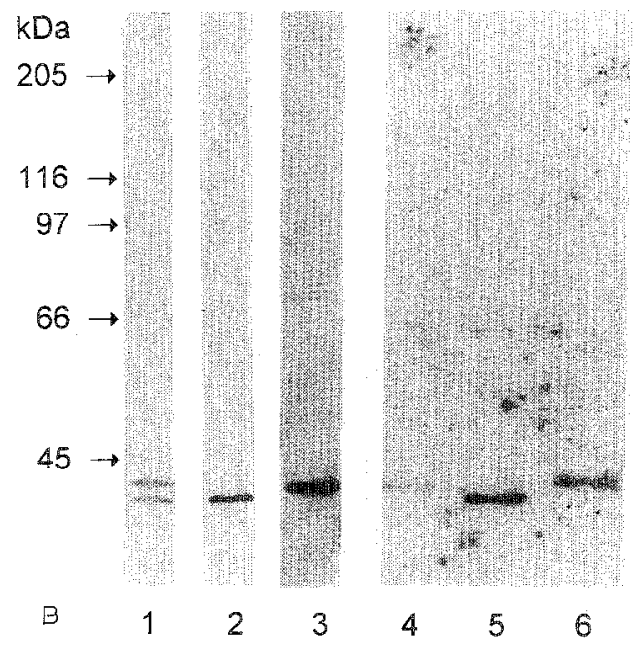

Fig. 5. The immunodetection of two forms of $\mathrm{CT}$. The soluble and particulate fractions from choline-depleted and choline-supplemented cells were separated by SDS-PAGE and transblotted onto PVDF membranes. (A) Lanes 1 and 5 contain purified CT 0.1 units enzyme activity); lanes 2 and 6 contain samples from the particulate fraction from choline-depleted cells (0.88 units); lanes 3 and 7 contain samples from the soluble fraction from choine-supplemented cells ( 0.96 units); and lanes 4 and 8 contain samples from the soluble fraction from choline-depleted cclls $(0.82$ units). Lanes $1-4$ were immunostained with $\mathrm{N}$-terminal antiserum. Lanes 5-8 were immunostained with $\mathrm{N}$-terminal antiserum plus 34 units of purified CT. (B) Lane 1 contains a mixture of the soluble fraction from cholinesupplemented cells and the particulate fraction from choline-deficient cells (each containing 0.33 units $\mathrm{CT}$ activity); lane 2 cuntains a sample from the particulate iraction from choline-depleted cells ( 0.66 units); lane 3 contains a sample from the soluble fraction from choline-supplemented cells ( 0.68 units); lane 4 contains purified CT (0.1 units enzyme activity); lane 5 contains a sample from the particulate fraction from choline-depleted cells $(0.88$ units); and lane 6 contains a sample from the soluble fraction from cholinesupplemented cells ( 0.96 units). Lanes $1-3$ were immunostained with antibodies raised against CT purified from Baculovirus-infected insect cells; lanes 4-6 were immunostained with antibodies raised against a peptide corresponding to an amino acid seuvence in the internal portion of $\mathrm{CT}$. antibodies raised against in incmal anino acid sequence of $\mathrm{CT}[14]$ (Fig. $5 \mathrm{~B}$, lanes $4-6$ ).

To verify that the two bands of CT detected in Fig. 5 were phosphorylated forms of $\mathrm{CT}$, we detemined the incorporation of ${ }^{32} \mathrm{P}$ into $\mathrm{CI}$ in choline repleter and choline-supplemented cells. CT was immonoprecipm itated with $\mathrm{N}$-terminal antiserum, resolved by $\$ D S$. PAGE, and transblotted onto PVDF membranes. The bands containing ${ }^{32} \mathrm{p}$ were detected by atoradiography and CT was then immunodetected whin N-termin. nal antiserum. The soluble fraction from cholinesupplemented cells contained ority the slower noving form of CT (Fig. 6, lane 1). This form of CT was highly phosphorylated (Fig. 6, lane 2). The soluble fraction from choline-depleted cells contained the fuster moy ing band of $\mathrm{Cl}$ (Fig. 6, lane 3). This fom was phosphorylated at a lower level (Fig. 6, lane 4). The meribrane fractions contained only the faster moving fom of $\mathrm{CT}$ (Fig. 6, lanes 5 and 7). The membrane fraction from choline-depleted cells contained more inmunodetectable Cl than the membrane fraction from choinesupplemented cels. The faster moving form also con. tained less $32 \mathrm{P}$. This is nost cvident by comparing lanes 1 and 2 to lanes 5 and 6 . Th these samples, the amount of immunodetectable $C T$ was simiter but the degree of phosphorylation was several-fold higher in the slower moving form (compare lane $2 \mathrm{vs}$ lane 6 ): These results demonstrate that the two bands reprem sent $C$ with different amounts of phosphorylation and are in complete agrement with results repotted prewiously for CT in CHO cells [13] and in Hena celis [16].

To obtain more deraled infomation about the rela. tionship between phosphorylation of Ch ard the release of CI from membranes, we detemined the relative amounts of the lower phosphorylated CT (TPCT) and the higher phosphorylated form (HPCT) during the development of choline-depleted cells. We also measured the phosphatidylcholine content and CT activity in the particulate fractions. The changes during choline depletion in phosphorylated foms of CT, the membrane C $\mathrm{T}$ activity and membrane phosphatich line content are shown in Fig. 7. This type of experiment was performed huree times will simblar resulls. The experiment shown in Fig. 7 used cells grown for 2 days in the presence or $50 \mu \mathrm{M}$ choline before replactment of the culture medium with cholne-deficient mediurl. This protocol resulted in a slower develop. ment of choline depletion. The membrane CT activity was low in cells grown with choline in the medinnt. Membrane CT activity remained low for the first $24 \mathrm{~h}$ of choline depletion (Fig. 7A). However, during the first $24 \mathrm{~h}$ of choline depletion phosphatidylcholne con. tent in cell membranes decreased abont $10 \mathrm{fg} P \mathrm{PC}$ phosphorus / mg cell protein; a decrease of about $20 \%$. Over the next $48 \mathrm{~h}$, membrane $\mathrm{CT}$ activity increased coincident with an additional decrease of abont $0.6 \mathrm{Hg}$ 
PC phosphorus/mg cell protein. The immunodetection of CT on Western blots demonstrated that the increase in membrane CT activity was due to an increase in CT protein (Fig. 7). Membrane CT was too low to detect in choline-supplemented cells and in cells after $10 \mathrm{~h}$ and $24 \mathrm{~h}$ in choline-deficient medium. At 24 $\mathrm{h}$, HPCT and LPCT were both present in the soluble fractions, indicating that dephosphorylation was beginning to occur. At 34 and $48 \mathrm{~h}, \mathrm{CT}$ in the soluble and particulate fractions was the LPCT form. The results at $24 \mathrm{~h}$ are instructive. Dephosphorylation of soluble CT was first detected at $24 \mathrm{~h}$. At this time CT activity and immunodetected CT was not increased in membranes. This result suggests that CT is dephosphorylated in cytosol before binding to membranes. The results at 34 $\mathrm{h}$ and $48 \mathrm{~h}$ indicate that dephosphorylation of CT is a prerequisite for binding but is not rate-limiting because CT continues to bind to membranes after all of the CT was converted to the LPCT form. A protein with an $M_{\mathrm{r}}$ of about 158000 was also detected in the particulate fractions. The identity of this protein is unknown but it may represent a complex between a CT-binding protein $\left(112000 M_{\mathrm{r}}\right)$ [35] and a $43000 M_{\mathrm{r}}$ subunit of CT since the $158000 M_{\mathrm{r}}$ protein was also detected by antibodies to the CT binding protein (Weinhold and Feldman, unpublished results).

The addition of choline to choline-depleted cells caused a rapid release of CT from membranes (Fig. 8A). An increase in membrane phosphatidylcholine content occurred coincident with the release of CT from membranes. This result agrees with results reported previously for hepatocytes isolated from choline-deficient rats [22,23]. In choline-depleted HepG2 cells both membrane-bound and soluble CT were LPCT, identified by comparison to the reference mixture of LPCT and HPCT (Fig. 8). Choline supplementation promoted the release of LPCT from membranes. Detectable phosphorylation of this form did not begin until most of the enzyme had been released. The HPCT form was present only after $120 \mathrm{~min}$ of choline supplementation. After $120 \mathrm{~min}$ of choline supplemen- tation nearly $80 \%$ of $\mathrm{CT}$ activity was released from membranes. This result clearly demonstrates that conversion to the highly phosphorylated form is not required for CT release.

The addition of $10 \mu \mathrm{M}$ choline was sufficient to increase the PC content and release membrane CT (Fig. 9). The results in Fig. 9A also illustrate the decrease in total CT activity that is often observed upon choline supplementation of choline-depleted cells. The results in Fig. 9 show that the decrease in membrane CT activity is due to release of enzyme protein from membranes. These results also suggest that the decrease in total CT activity may be due to a transitory, inactivation of the released CT. At $10 \mu \mathrm{M}$ choline, CT activity and immunodetected protein were nearly completely released from membranes, but the CT activity was not completely recovered in the soluble fraction.

\section{Discussion}

HepG 2 cells were depleted of choline by exposing cells to choline-deficient culture medium. The depletion of phosphocholine effectively decreased the synthesis of phosphatidylcholine by the CDP-choline pathway. The decreased incorporation of $\left[{ }^{3} \mathrm{H}\right] \mathrm{glycerol}$ into phosphatidylcholine provided direct evidence that the synthesis of phosphatidylcholine by the CDP-choline pathway was reduced. In response to the depleted supply of choline, CT was translocated to membranes, in an attempt to increase the activity of the pathway. The increase in the active form of CT resulting from the translocation may provide for more efficient utilization of the choline and phosphocholine produced from turnover of PC. Choline depletion also induced a rapid increase in the methylation pathway. This result is consistent with reports by others that choline deficiency causes an increase in the methylation pathway [39-44]. Although phosphatidylcholine levels decreased in choline-depleted cells, the increase in the methylation pathway apparently provided sufficient

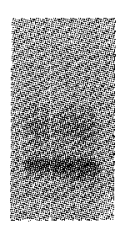

1

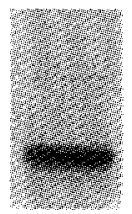

2

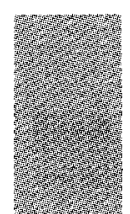

3

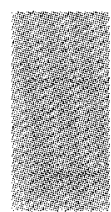

4

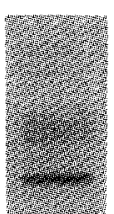

5

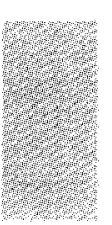

6

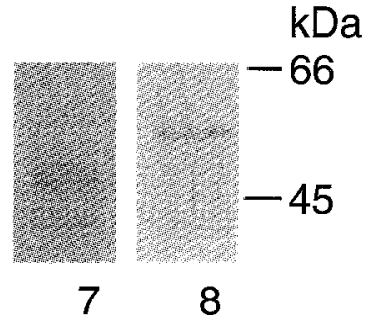

Fig. 6. The two forms of CT represent different levels of CT phosphorylation. CT was immunoprecipitated from choline-depleted and choline-supplemented cells labelled with ${ }^{32} \mathrm{PO}_{4}$. Phosphorylated CT was detected by autoradiography (lanes $2,4,6,8$ ). The mass of CT in each lane was then immunostained with $\left[{ }^{125} \mathrm{I}\right] \mathrm{IgG}$ prepared from $\mathrm{N}$-terminal antiserum (lanes 1, 3, 5, 7). Lanes 1 and 2 contain samples from the soluble fraction of choline-supplemented cells; lanes 3 and 4 contain samples from the soluble fraction of choline-depleted cells; lanes 5 and 6 contain samples from the particulate fraction of choline-depleted cells; lanes 7 and 8 contain samples from the particulate fraction of choline-supplemented cells. 

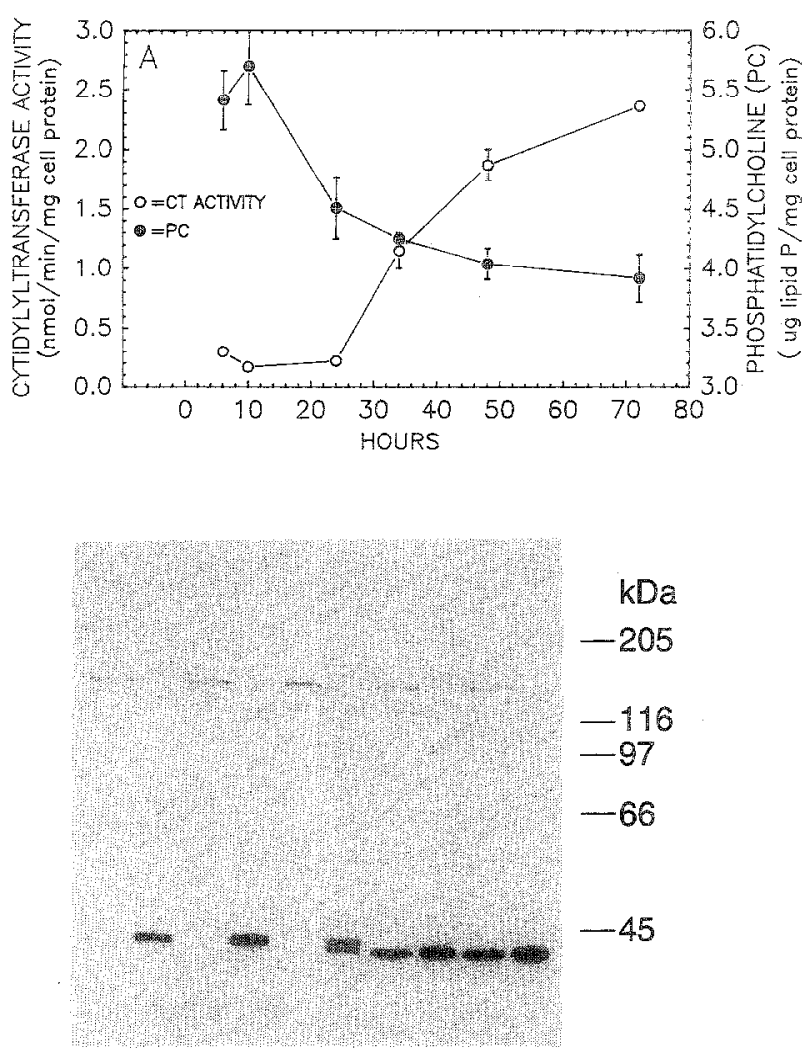

123345567788910

Fig. 7. Changes in CT activity, phosphorylated forms of CT and membrane phosphatidylcholine content during choline depletion of HcpG2 cclls. Cells were cultured for 3 days in MEM $+10 \%$ FCS. The medium was then replaced with MEM supplemented with 50 $\mu \mathrm{M}$ choline. After $24 \mathrm{~h}, 3$ dishes of choline-supplemented cells (CS) were collected. The medium in the remaining dishes was replaced with choline-deficient MEM. Cells were collected after different periods of choline depletion (CD). Cells frum each dish were treated with digitonin to obtain a soluble fraction (digitonin released) and a total particulate fraction. (A) CT activity and phosphatidylcholine content in the total particulate fraction after digitonin permeabilization. The values are averages of three dishes. The error bar represents the S.D. Where no bar is present, the S.D. was less than the size of the data point. A Western blot of soluble and particulate fractions from choline-supplemented and choline-depleted cells from (A) is shown in the bottom panel. Aliquots $(80 \mu 1)$ from the soluble fraction ( $600 \mu 1$ total volume) and from the particulate fraction (400 $\mu 1$ total volume) were separated by SDS-PAGE (10\% polyacrylamide) and transblotted onto PVDF membranes. Lane 1, CS particulate; lane 2, CS soluble; lane $3,10 \mathrm{~h} \mathrm{CD}$ particulate; lane $4,10 \mathrm{~h} \mathrm{CD}$ soluble; lane $5,24 \mathrm{~h}$ CD particulate; lane $6,24 \mathrm{~h}$ CD soluble; lane 7 , $34 \mathrm{~h} \mathrm{CD}$ particulate; lane $8,34 \mathrm{~h} \mathrm{CD}$ soluble; lane $9,48 \mathrm{~h} \mathrm{CD}$ particulate; lane $10,48 \mathrm{~h}$ CD soluble.

phosphatidylcholine to maintain cell growth and viability. The rat hepatoma cell line R-Y121 B-CHO also has been shown to grow in the absence of choline and to possess an increased methylation pathway [45].

We estimated the half-life of phosphatidylcholine to be $20 \mathrm{~h}$. The half-life of phosphatidylcholine in CIIO$\mathrm{K} 1$ cells was estimated to be $15 \mathrm{~h}$ [46]. Tijburg et al. [47] reported that the addition of choline and methionine to hepatocytes isolated from choline- and meth- ionine-deficient rats increased the rate of phosphan tidylcholine catabolism. However; we found that in HepG2 cells choline depletion did not appear to change the turnover rate for phosphatidylcholine. The differences in the effects of choline on tumover may be due to inherent differences between. HepG2 cells and rat liver hepatocytes. On the other hand, the hopatocyte experiments involved deficiencies in both choline and methionine whereas in the HepG2 experiments only choline was depleted. Thus, the synthesis of phosphatidylcholine in the hepatocyte model was restricted 10 a greater extent than in the HepG2 cells. This may lead to changes in the catabolism of phosphatidylcholine.
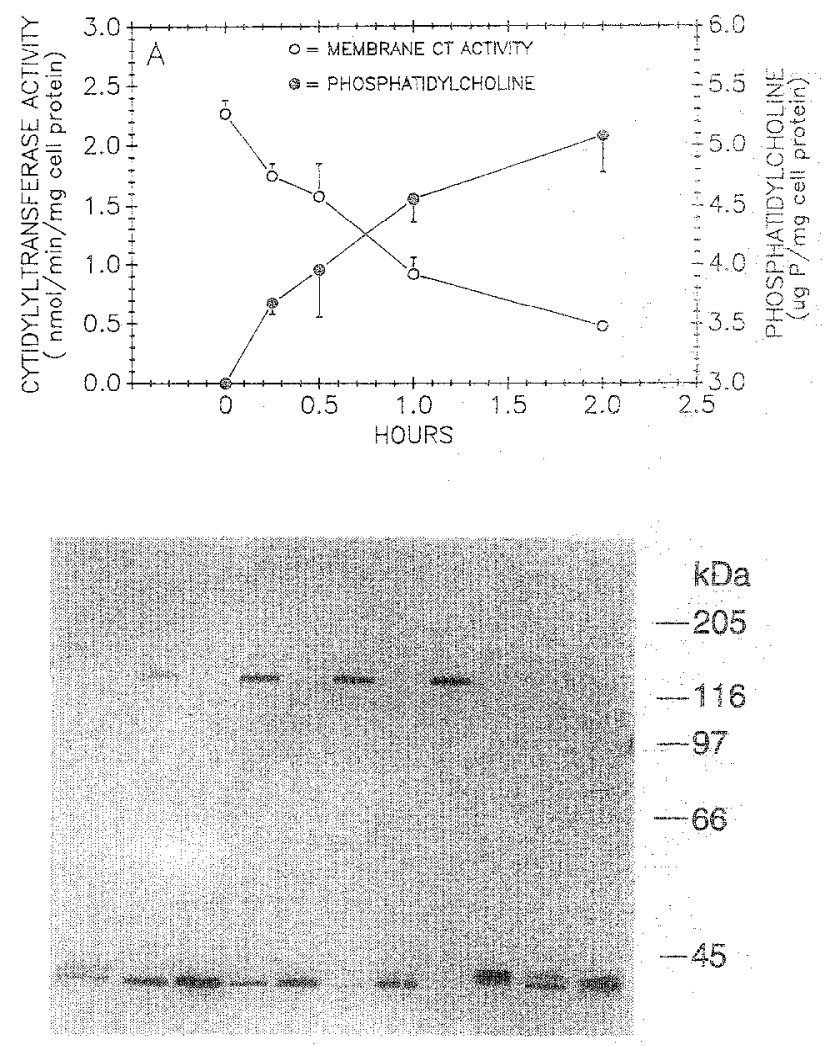

$\begin{array}{lllllllllll}1 & 2 & 3 & 4 & 5 & 6 & 7 & 8 & 9 & 10 & 11\end{array}$

Fig. 8. Changes in $\mathrm{CT}$ activity, phosphorylated forms of $\mathrm{CT}$ and membrane phosphatidylcholine content after choline supplementation. Cells were cultured for 3 days in MEM $+10 \%$ FCS. The medium was then replaced with choline-deficient MEM and the cels were cultured for $48 \mathrm{~h}$. The medium on the cholinedepleted (CD) cells was then changed to choline-supplemented (CS) rnedium and collected at the designated times. (A) Menbrate $C T$ activity and phosphatidylcholine content. The values are averages of 3 dishes. The error bars represent the S.D. Where no bar is present, the S.D. was less than the size of the data point. A Westenin blot of samples from $(A)$ is shown in the bottom panel. The samples were prepared as described in Fig. 7. Lanes 1 and 10 contain in milute of CS soluble fraction and $C D$ soluble fraction, serving as reference markers for the two forms of CT (LPCT, faster band, HPCT, slower band); lane 2, CD particulate; lane 3, CD soluble; lane 4, 30 min CS particulate; lane $5,30 \mathrm{~min}$ CS solubie; lane $6,60 \mathrm{~min}$ CS particulate; lane 7,60 min CS soluble; lane 8,120 min CS particuldte; 1ane-9, 120 min CS soluble; lane 11, purified $\mathrm{CT}$. 

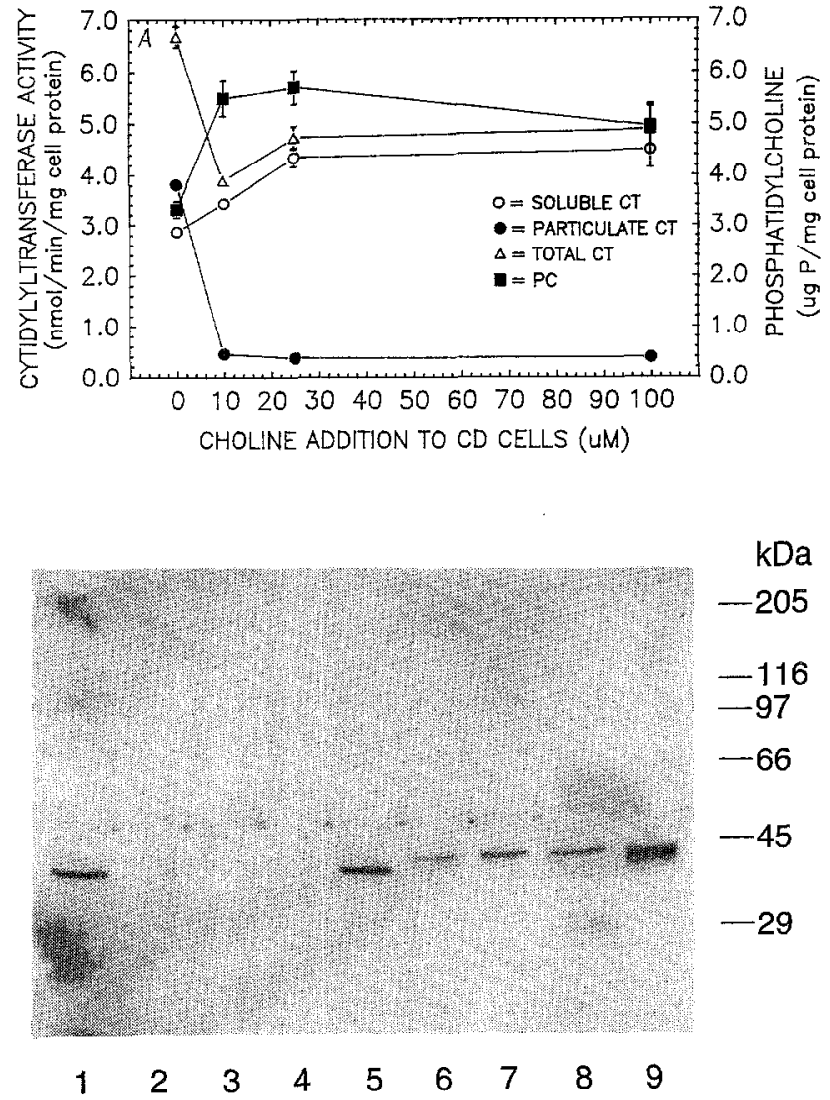

Fig. 9. Effect of choline concentrations on the release of CT from membranes. Cells were cultured for $48 \mathrm{~h}$ in choline-deficient MEM. The medium was then changed to choline-deficient medium supplemented with $10 \mu \mathrm{M}, 25 \mu \mathrm{M}$ and $100 \mu \mathrm{M}$ choline. After $3 \mathrm{~h}$, cells were collected and treated with digitonin to separate the soluble and the particulate forms of CT. (A) CT activity and membrane phosphatidylcholine content. The values are averages of 3 dishes. The error bars represent one S.D. When no bar is present, the S.D. was less than the size of the data point. A Western blot of samples from (A) is shown in the bottom panel. Aliquots $(60 \mu \mathrm{l})$ of the soluble fraction (digitonin released) and the particulate fraction were prepared as in Fig. 7 and separated by SDS-PAGE ( $8 \%$ polyacrylamide). Lane 1, CD particulate; lane 2, $10 \mu \mathrm{M}$ CS particulate; lane 3, 25 $\mu \mathrm{M}$ CS particulate; lane $4,100 \mu \mathrm{M}$ CS particulate; lane 5 , CD soluble; lane 6, $10 \mu \mathrm{M}$ CS soluble; lane 7, $25 \mu \mathrm{M}$ CS soluble; lane 8, $100 \mu \mathrm{M} \mathrm{CS}$ soluble; lane 9, purified CT.

Although it is clear that CT cxists as a phosphorylated protein [12-18], the functional significance of CT phosphorylation is not fully understood. Watkins and Kent identified two phosphorylated forms of CT in Chinese hamster ovary cells (CHO); a lower phosphorylated form (LPCT) that migrated faster in SDS gels, and a higher phosphorylated form (HPCT) that migrated slower in SDS gels [13]. Phospholipase C treatment of CHO cells produced an increase in LPCT in the membrane fractions. Our results provide additional support for the existence of LPCT and HPCT and offer new insight into the role of phosphorylation and dephosphorylation in the translocation of CT. The presence of LPCT and HPCT in HepG2 cells, agrees with the results for CHO cells [13]. Examination of the interconversions of LPCT and HPCT, induced by changes in the cellular content of choline, provided direct evidence for the involvement of phosphorylation in CT translocation. Choline-supplemented HepG2 cells contain only HPCT. Choline depletion of HepG2 cells induces dephosphorylation of HPCT to LPCT and the binding of LPCT to membranes. In cholinedepleted cells, only LPCT is present in both the soluble and membrane fraction. Moreover, comparison of kinetics of binding and release of $C T$ with the phosphorylation and dephosphorylation of CT indicates that both the formation of LPCT and HPCT occur in the soluble fraction. The fact that LPCT is released from membrane before it is converted to HPCT provides strong evidence that the release is triggered by changes in the binding properties of the membranes and not by phosphorylation of LPCT.

Results reported by Jamil et al. $[23,48]$ with hepatocytes from choline and methionine deficient rats provided evidence suggesting that the membrane content of phosphatidylcholine regulated the binding of CT to membranes by a feedback mechanism and that changes in the state of phosphorylation was apparently not required. In this mechanism, a decrease in phosphatidylcholine promotes the binding of CT. A similar mechanism was proposed earlier to explain the translocation of CT in choline-deficient LM and CHO cells [19]. Our results provide additional evidence that a change in membrane phosphatidylcholine content may be involved in the translocation mechanism. However, in contrast to the results reported by Jamil et al. [23], we obtained evidence indicating that phosphorylation was also involved.

We suggest, therefore, that translocation requires both the induction of CT binding site on membranes and dephosphorylation of HPCT to LPCT in cytosol. The release of CT from the membrane sites is controlled primarily by changes in the membrane binding site. Once CT is released from the membrane, phosphorylation converts LPCT to HPCT which effectively traps the CT in the soluble pool. This mechanism provides a high degree of regulation and would enable cells to coordinate different signals with appropriate responses. For cxample, if a signal triggered the dephosphorylation of HPCT to LPCT but phosphatidylcholine content on membrancs was not decreased, an increase in phosphatidylcholine synthesis would not be necded and CT translocation would not occur.

The mechanisms for the induction of $\mathrm{CT}$ binding sites on membranes are still poorly understood. The present results along with those from choline-deficient hepatocytes $[23,48]$ suggest that $\mathrm{CT}$ binding sites are produced by a depletion of phosphatidylcholine in the membrane. However, CT binding to membranes can also be induced by fatty acids [3-11] and perhaps by diacylglycerol [17] without measurable changes in phos- 
phatidylcholine content [25]. Direct evidence that fatty acids or diacylglycerol operate in cells to modify membranes, as opposed to effects on soluble $\mathrm{CT}$, has not been reported. However, the modification of membrane binding sites is a reasonable hypothesis because these compounds promote binding of $\mathrm{CT}$ to artificial membranes $[49,50]$ and induce in vitro translocation of $\mathrm{CT}$ to cellular membranes [51,52]. Jamil et al. [53] proposed that $\mathrm{CT}$ binding to membranes is related to the ratio of bilayer forming to non-bilayer forming lipids in the membranes. They argued that most conditions that lead to an increase in membrane-bound $\mathrm{CT}$ produced a decrease in the ratio of bilayer forming to non-bilayer forming lipids in the membranes. Clarification of the role of membrane modification in the control of CT translocation will require the identification and characterization of membrane binding sites or domains. Recent in situ localization studies indicate that both soluble and membrane-bound $\mathrm{CT}$ are located in the nucleus $[28,54]$. The increase in membrane-bound CT resulting from choline depletion of the HepG2 cells appeared to occur in the nuclear membrane (Weinhold and Kent, unpublished results). Thus, studies of $\mathbb{C T}$ binding to isolated nuclear membranes may provide further insight into the induction of $\mathrm{CT}$ binding sites in membranes and the molecular forms of CT bound to membranes.

\section{Acknowledgements}

We thank Dr. Claudia Kent for providing N-terminal CT antiserum, Dr. James MacDonald and Dr. Claudia Kent for making available antibodies against recombinant CT, and Dr. Dennis Vance for providing antibodies to an internal amino acid sequence of Cll. This work was supported by the Department of Veterans Atfairs and by Grant HD02871 from the National Institute of Child Health and Human Development, National Institutes of Health.

\section{References}

1 Vance, D.E. (1990) Biochem. Cell Biol. 68, 1151-1165.

2 Kent, C. (1990) Prog. Lipid Res. 29, 87-105.

3 Pelech, S.L., Pritchard, P.H., Brindley, D.N. and Vance, D.E. (1983) J. Biol. Chem. 258, 6782-6788.

4 Pelech, S.L., Cook, H.W., Paddon, H.B. and Vance, D.E. (1984) Biochina. Biophys. Acta 795, 433-440.

5 Whition, D.S., Anderson, K.E. and Mueller, G.C. (1985) Biochim. Biophys. Acta 835, 369-377.

6 Aeberhard, E.E., Barrett, C.T., Kaplan, S.A. and Scott, M.L. (1986) Biochim. Biophys. Acta 875, 6-11.

7 Chander, A. and Fisher, A.B. (1988) Biochim. Biophys. Acta 958, 343-351.

8 Burkhardt, R., Von Wichert, P. Batenburg, J.J. and Van Golde, L.M.G. (1988) Biochem J. 254, 495-500.

9 Mock, T., Slater, T.L., Arthur, G., Chan, A.C. and Choy, P.C. (1986) Biochem. Cell Biol. 64, 413-417.
10 Blank, M.L., Lee, Y.J., Cress, E.A. and Snyder, F. (1988) J. Biol. Chem. 263, 5656-5661.

11 Weinhold, P.A. Charles, L., Rounsiler, M.E. and Feldman, D.A. (1991) J. Biol. Chem. 266, 6093-6100.

12 Watkins, J.D. and Kent, C. (1990) J, Brol. Chem. 265, 2190-2197.

13 Watkins, J.D, and Kent, C. (1991) I. Biol, Chem. 266, 2113-m 21117.

14 Jamil, H., Utal, A.K. and Vance, D.E. (1992) Biol. Chem 267 , $1752-1760$.

15 Ilatch, G.M., Jamil, H., Utâl, A.K. and Vance, D.E. (1992) J. Biol. Chem. 267, 15751-15758.

16 Wang, Y., MacDonald, J.I.S., and Kent, C. (1993) I. Biol. Chem. $268,5512-5518$.

17 Utal, A.K., Jamil, H. and Vance, D.E. (1991) J. Bior. Chem. 266, 24084-24091.

18 Watkins, J.D., Wang, Y. and Kent, C. (1992) Arch. Bochem. Biophys. 292, 360-367.

19 Sleight, R. and Kent, C. (1983) J. Biol Chem. 258, 836-859.

20 Maedo, M., Nisbijina, M., Akamatsu, Y. and Sakakibara, Y. (1985) J. Biol. Chem. 260, 5925-2930.

21 Tesan, M., Anceschi, M.M. and Bleasdale, J.E. (1985) Biochem. J. $232,705-713$.

22 Yao, Z., Jamil, H. and Vance, D.E. (1990) J. Bol. Chem, 265, $4326-4331$.

23 Jamil, H., Yao, Z. and Vance, D.E. (1990) J. Biol. Chen. 265 , $4332-4339$

24 Sleight, $\mathbb{R}$. and Kent, C. (1983) J. Biol. Chem. 258, 824-830.

25 Terce, F., Record, M.s Tronchere, H., Ribbes, G. and Chap, $\mathrm{H}$. (1991) Rinchim. Biophys. Acta 1084, 69-77.

26 Knowles, B.B., Howe, C.C. and Aden, D.P. (1980) Science 209, $497-499$.

27 Javitt, N.B. (1990) FASEB J. 4, 161-168.

28 Watkins, J.D. and Kent, C. (1992) J. Biol. Chem. 267, 5686-5692.

29 MacDonald, J.IS. and Kent, C. (1993) Prot. Express. Purif. A, $1-7$.

30 Balch, W.E. and Rothman, J.E. (1985) Arch. Biochem. Biophys. $240,413-425$.

31 Weinhold, P.A., Rounsifer, M.E., Charles, L. and Feldman, DA. (1989) Biochim. Biophys. Acta 1006, 299-310.

32 Weinhold, P.A. and Feldman, D.A. (1992) Methods Enzymol. $209,248-258$.

33 Weinhold, P.A., Charles, L. and Feldman, D.A. (1991) Biochim. Biophys. Acta 1086, 57-62.

34 Weinhold, P.A. and Villee, C.A. (1965) Biochim. Biophys. Acta $106,540-550$

35 Feldman, D.A. and Weinhold, P.A. (1993) I. Biol Chem 268, $3127-3135$

36 Haisma, H.J., Hilgers, J. and Zurawski, V.R (1986) J. Nuel Med. $27,1890-1895$.

37 Markwell, M.K., Haas, S.M., Beiber, L.L. and Tolbert, N.: (1978) Anal. Biochem. 87, 206-210.

38 Labarca, C. and Paigen, K. (1980) Anal. Biochem. 102, 344--352.

39 Wells, I.C. and Remy, C.N. (1965) Arch. Biochem. Biophys. 112 201-206.

40 Thompson, W., MacDonald, G. and Mookeriea, S. (1969) Biochincr. Bioplyys. Acta 176, 306-315.

41 Lombardi, B., Pani, P., Schlunk, F.F. and Shi-hia, C. (1969) Lipids, 4, 67-75.

42 Glenn, J.L. and Austin, W. (1971) Biochim. Biophys. Acta 231; $153-160$.

43 Sclueider, W.J. and Vance, D.E. (1978) Eur. 3. Biochem. 85, $181-187$.

44 Daiko, A.H., Aksamit, R.R. and Mudd, S.H. (1990) Lipids 25, $135-142$.

45 Yamamoto, K., Niwa, A. and Yasumura, w, (1985) J. Cell. Physiul. $125,91-97$. 
46 Nishijima, M., Kuge, O., Maeda, M. Nakamo, A. and Akamatsu, Y. (1984) J. Biol. Chem. 259, 7101-7108.

47 Tijburg, L.B.M., Nishimaki-Mogami, T. and Vance, D.E. (1991) Biochim. Biophys. Acta 1085, 167-177.

48 Jamil, H. and Vance, D.E. (1990) Biochem. J. 270, 749.754.

49 Feldman, D.A., Rounsifer, M.E. and Weinhold, P.A. (1985) Biochim. Biophys. Acta, 429, 429-437.

50 Cornell, R. and Vance, D.E. (1987) Biochim. Biophys. Acta 919, $37-48$.
51 Weinhold, P.A., Rounsifer, M.E., Williams, S.E., Brubaker, P.G. and Feldman, D.A. (1984) J. Biol. Chem. 259, 10315-10321.

52 Cornell, R. and Vance, D.E. (1987) Biochim. Biophys. Acta 914, 26-36.

53 Jamil, H., Hatch, G.M. and Vance, D.E. (1993) Biochem. J. 291, 419-427.

54 Wang, Y., Sweitzer, T.D., Weinhold, P.A. and Kent, C. (1993) J. Biol. Chem. 268, 5899-5904. 